\title{
Internalization of Multicultural Values through the Education Process in Manado State University
}

\author{
Mardan Umar ${ }^{1, a^{*}}$, Jeinica Firginia Tumiwa $a^{1, b}$ \\ 1Department of Pancasila and Civic Education, Faculty of Social Sciences, Universitas Negeri Manado, Sulawesi Utara, Indonesia \\ a mardanumar@unima.ac.id; b jeinicatumiwa@gmail.com \\ ${ }^{*}$ Corresponding Author \\ Whatsapp Number [085256031165]
}

How to Cite:. Umar, M., Tumiwa, J., F. (2020). Internalization of Multicultural Values through the Education Process in Manado State University. International Journal for Educational and Vocational Studies, 2(8), 720-725. DOI: https://doi.org/10.29103/ijevs.v2i8.2688

\section{ARTICLE HISTORY}

Received: 4 June 2020

Revised: 8 July 2020

Accepted: 24 July 2020

\section{KEYWORDS}

Diversity;

Multicultural values;

Culture;

Religion;

Moral;

\begin{abstract}
This study aims to describe the internalization of multicultural values for students at Manado State University. The diversity of Indonesian society is a rich gift of God. Therefore, this diversity must be managed properly in order to have a positive impact on the people of Indonesia. Differences should not be a reason for conflict in the community. One effort that can be done is to internalize multicultural values through the education process. This research uses a descriptive qualitative approach related to the process of internalizing multicultural values in Manado State University students, especially in the Faculty of Social Sciences as the object of research. Data obtained through observation, interviews and documentation, while data analysis is done by the process of presenting data, data reduction, and drawing conclusions. The results of this study indicate that the internalization of multicultural values is developed through learning activities in the classroom through Multicultural Education, Religious Education, and Values and Moral Education courses. In addition, the internalization of values is also carried out through student activities and interactions within the faculty and university environment.
\end{abstract}

\section{INTRODUCTION}

One of the important programs for countries that have diversity is the Multicultural Education program, because diversity in the community can potentially bring a beautiful harmony in life and is rich in culture, but on the other hand it can lead to conflicts caused by differences in cultural, religious, racial, ethnic and cultural backgrounds. group In this condition, multicultural education is needed in order to provide citizens with an understanding of the importance of respecting differences, positive interactions, tolerance, cooperation, and willingness to coexist peacefully in diversity.

Several results of research have revealed that multicultural education has had a positive impact on increasing tolerance, respecting differences, giving freedom to others in expressing beliefs, accepting diversity and interacting without questioning differences (Miftakhul et al., 2020), because multicultural education is an educational strategy that can be applied to all subjects by using students' cultural differences such as ethnicity, religion, language, gender, social class, race, ability and age to facilitate the learning process (Ainul Yaqin, 2005), so it needs to be implemented in every - educational institution and society (Bruch et al., 2004), in particular improves communication between diverse cultural differences (Bruch et al., 2005).

As a heterogeneous country, Indonesia has Pancasila as a philosophical system that animates the life of the nation and state (Dewantara et al., 2019). Pancasila is an ideology of the nation that accommodates all differences. So that differences in the territory of the Republic of Indonesia are natural and can be well received. However, the facts in Indonesia still often occur conflicts due to differences in culture, religion, ethnicity, and class. according to Iqbal (Iqbal, 2014), a multicultural society holds the potential for conflict. A number of horizontal conflicts occur between different members of the community.

This is a threat to the life of the Indonesian people who have a diversity of cultures, ethnicities, and religions. Data from Kompas Research and Development as quoted by Iqbal (Iqbal, 2014) shows threats to Indonesian nationality including regional sentiments, religious sentiments, the influence of globalization culture, minimal attention to local culture, national leadership. 
Table 1. Threats to Indonesian Nationality

\begin{tabular}{cc}
\hline Threats & $(\%)$ \\
\hline Regional Sentiments & 60,3 \\
Religious Sentiments & 56,8 \\
Influence Of Globalization Culture & 53,3 \\
Minimal Attention To Local Culture & 81,5 \\
National Leadership & 90,0
\end{tabular}

Note: The data source: Kompas Research and Development in 2012 as quoted by lqbal, 2014.

This heterogeneity and diversity often turn out to be a threat to the unity of the nation and state. Even though the Indonesian people were convinced that all citizens could unite in the difference of "Bhineka Tunggal Ika" (Unity in Diversity). The assumption that diversity will endanger the integrity of the nation, is a strong reason to make multicultural education efforts for Indonesian citizens to accept differences as the reinforcement of national unity.

The lack of a comprehensive understanding of multiculturalism has caused respect for differences to begin to decline. Togetherness, appreciation and respect for others, and cooperation began to disappear. Excessive pride in one's own culture also results in a lack of understanding in interactions with other cultures and various other phenomena that occur that require us to pay attention to the importance of multicultural education. Therefore, this research is considered very important to place the position of multicultural education as a solution to the threat of national disintegration.

According to Liliweri, multicultural education is an educational strategy that utilizes the diversity of cultural backgrounds of students as one of the strengths to form multicultural attitudes (Liliweri, 2005). Students are expected to have a good understanding of multiculturalism in order to be able to realize the importance of togetherness, cooperation, tolerance, respect for others, and interact positively in the diversity of society. This is important, because multicultural education teaches about diversity (Baidhawi, 2005). Through multicultural values education efforts, students are formed to respond proportionally and productively to diversity and difference in building a harmonious society. Because the realization of a harmonious society in diversity is the goal of multicultural education (Ibrahim, 2013).

The process of implementing multicultural education programs must be able to respond to differences. Banks outlines five dimensions consisting of: 1) content integration, which is the dimension used to provide learning information by reflecting on different material; 2) knowledge construction, namely the teacher helps students to understand multiple perspectives and formulate conclusions; 3) prejudice reduction, the teacher tries to help students in developing positive behavior about group differences; 4) Equitable pedagogy, which is a strategy in treating education equitably, among other things with the form of cooperation (cooperative learning), and not in competitive ways (competition learning); and 5) empowering school culture and social structure, which is structuring social structures (schools) that utilize the diverse cultural potential of students as characteristics of school structures.

Well programmed efforts can help internalize multicultural values in students and and the future of Indonesia (Kerebungu et al., 2019). Based on the description above, regarding the urgency of multicultural values, this research about Internalization of Multicultural Values, especially for students at Manado State University is very important.

\section{METHODS}

This study uses a qualitative approach that emphasizes qualitative data and information and is presented in a descriptive form. This research is a field research that focuses on the learning process of multicultural education in educating the values of diversity in students at Manado State University. Data obtained through observation and interviews with data sources namely lecturers and students. In addition, the data in this study were also sourced from documentation data such as documents and photos of activities. Researchers analyze and describe research findings descriptively using the Milles \& Huberman model flow, namely: data reduction, data presentation, verification and conclusion drawing (Sugiyono, 2017); (Miles \& Huberman, 1992). To check the validity of the data, researchers used a triangulation technique. Triangulation used is technical triangulation, source triangulation and time triangulation with the aim that researchers obtain valid data.

\section{RESULTS AND DISCUSSION}

\subsection{Results}

Based on the research findings obtained information that the internalization of multicultural values is done by including Multicultural Education courses in the education curriculum at Manado State University, especially in the Faculty of Social Sciences. Multicultural Education courses are very important for students, especially Manado State University, which has a diversity of student backgrounds from regions rich in culture.

Based on the research findings obtained information that the internalization of multicultural values is done by including multicultural education courses in the education curriculum at Manado State University, especially in the Faculty of Social Sciences.

Multicultural Education courses are very important for students, especially Manado State University, which has a diversity of student backgrounds from regions rich in culture. So that multicultural education is very appropriate given to students as part of the education curriculum. Internalization of multicultural values in education at Manado State University can be described as follows: 
1. Learning Multicultural Values.

Internalization of multicultural values is carried out through Multicultural Education (ME) subject learning and religious education. On multicultural education courses, students are taught about the cultural diversity of Indonesian people as ancestral heritage. Indonesia as a country where various tribes, religions, races and groups meet to give broad space and equal rights to all citizens to live and develop their culture, customs and beliefs in each of their life activities.

Multicultural Education (ME) Learning is carried out programmatically every year and must be followed by all students, especially in the Department of Pancasila and Citizenship education. Students conduct discussions about the development of Indonesian culture, and cultural conditions in modern times. In addition, the lecturer provides the opportunity for students to make observations about the diversity of the community, make an analysis of the problem then formulate steps to anticipate the occurrence of conflict. Multicultural Education Learning uses problem based learning and cooperative learning strategies, so students are more active in each learning process. This learning process has increased students' understanding of diversity and multiculturalism in Indonesian society.

In addition to learning Multicultural Education, the process of internalizing multicultural values is also carried out through Religious Education (RE) courses. The Lecturer of Religious Education (RE) provides an understanding of the importance of religious tolerance, respecting the diversity of streams in one religion and respecting the freedom of others in religion and belief to establish harmonious relationships between adherents of different religions.

If Multicultural Education (ME) uses a multicultural approach based on Pancasila and the Basic Law, then Religious Education (RE) uses a religious approach based on the respective religious Scriptures, such as the Koran, the Bible, Wedha, and other holy books in accordance with the religious education being taught. Because, all the holy books teach followers to respect differences, respect for others, tolerance, and avoid conflicts.

Table 2. Multicultural Values in the Learning Process

\begin{tabular}{cc}
\hline Multicultural Values & Course \\
\hline Accept Cultural Differences & ME \\
Respect for others & ME \& RE \\
Cooperate with people from different cultures & ME \& RE \\
Appreciate differences in beliefs & RE \\
Tolerance & RE \\
\hline
\end{tabular}

Note:

ME : Multicultural Education, RE : Religious Education

\section{Habituation and Modeling.}

Learning value does not always only prioritize the transformation of knowledge, but it requires a process of modeling and habituation. Students who have an understanding of multiculturalism are trained to implement multicultural values in daily interactions with friends. On the other hand, the lecturer participated in giving a good example. such as being fair, respecting differences, tolerance, working together, and avoiding conflict. A positive lecturer attitude is a valuable example for students. Social interaction among students and between students and lecturers that reflect multicultural values can internalize multicultural values in students life.

\section{Rewards and Punishment; Appreciation and Reprimand}

Rewards and Punishment are concepts commonly used at the level of early childhood education, or primary and secondary education. However, at the college level, this step can be used on students to emphasize that every action has consequences for personal life and social life. Thus, the reprimand and punishment will give a deterrent effect on students who violate multicultural values such as students who demean other tribes, act unfairly, and do not accept differences. On the other hand, awards and appreciation are given to students who prioritize multicultural values in their daily activities. Cooperation without differentiating between tribes, religions, and groups shows the positive interaction of students. Learning in heterogeneous groups, sitting and discussing with friends from different ethnic groups is a form of effective communication in internalizing multicultural values at Manado State University.

Student pride in religion, culture, region and ethnicity is manifested by forming groups and organizations in accordance with their respective religions, ethnicities and cultures. Badan Tadzkir Mahasiswa (BTM) for Muslim Students, Christian and Catholic Student Service Units, as well as Hindu student groups, is a student association based on religion. There are also organizations and associations based on regional origin such as Papuan students, Ternate, Bolaang Mongondow, Gorontalo, as well as Javanese, Sumatran and other student associations. Even though each religion, tribe and region has a unique student organization, it is often carried out joint activities across different organizations.

Based on the above research findings, it can be stated that the internalization of multicultural values is implemented through learning activities with the transformation of knowledge and cultural construction of each region and religion. Then, the example and habituation of lecturers and students in every activities and interactions, as well as the application of rewards and penalties for students in the form of a reprimand if there is a violation of multicultural values, both cultural and religious. Internalization of multicultural values is also supported by cross-organization activities and student associations with different cultural and religious backgrounds. All these efforts strongly support the realization of a peaceful and harmonious life in diversity. 


\subsection{Discussions}

The process of internalizing values can be done through value transformation, value transactions and the value trans-internalization stage (Hakam \& Nurdin, 2016). Value transformation is the process of informing values through a process of verbal communication. So this process is only a process of transformation of knowledge (cognitive) about a certain value. While the value transaction, is the process of internalizing values through two-way communication between educators and students in a reciprocal way, so that the interaction process occurs between them. This process allows educators to influence the value of students through examples of the value that is run (modeling) while students can accept new values adjusted to their values.

In addition to the process of transformation and value transactions, there is also a process of trans-internalization of values, namely the process of internalizing values through a process that is not only verbal communication but also accompanied by personality communication displayed by educators through modeling, through conditioning and through the habituation process to behave in accordance with expected values. So students are invited to understand values, are trained to actualize values, get concrete examples in implementing values, familiarize themselves with a value and actualize values in daily life. In this context, internalization of values includes the cognitive, affective and psychomotor domains (Hakam \& Nurdin, 2016).

The results of this study are in accordance with the internalization theory proposed by (Hakam \& Nurdin, 2016) which states that the internalization process is carried out through value transformation, as in this study it was found that the internalization of multicultural values is done through learning Multicultural Education and Learning Religious Education. In addition, the internalization of multicultural values at Manado State University is also carried out with value transactions and the internalization of values through discussion and communication between educators and students as well as through modeling from educators to students in daily activities.

The term multicultural is identical to culture. Although the term is still being debated, there seems to be some kind of agreement that culture is language, history, beliefs, moral values, geographical origins and everything that is peculiar to the group (Pradipto, 2005). Culture, of course, differs from one group to another with their respective characteristics. So that in a society can be found cultural differences or multicultural community life. According to Kymlicka multiculturalism is a recognition, respect and justice for ethnic minorities both concerning universal rights inherent in the rights of individuals and communities that are collective in expressing their culture.

In this research, more cultural issues emerge in the learning of Multicultural Education as part of the education curriculum. So the discussion about multiculturalism with their respective cultural approaches is very interesting for students. Discussions about respect for culture are also very positive conducted by students to get to know each other and understand cultural differences to avoid misunderstandings when interacting. Multicultural Education learning has eliminated minority and majority barriers between students, so that justice, equal rights and opportunities are felt by all students. In accordance with Binyamin's opinion which states that good relations between groups, both majority and minority need to be realized in tolerance and equality (Paul-Binyamin \& Haj-Yehia, 2019).

Increased understanding of other people's cultures has had a positive impact on the attitude of respect for differences between students. Therefore, Multicultural materials must be included in the education curriculum at all levels of education. In line with the opinion of Andersen and Cuhser that cultural diversity becomes subject matter that must be considered by curriculum developers (Andersen \& Cusher, 1994). With an educational curriculum that favors multicultural values, it is expected that internalization of multicultural values can take place properly. Therefore, education is still considered as an effective way of internalizing a value.

Education must be able to pay attention to the social conditions of the community and make appropriate changes so that education can optimize its role as a social reconstruction (Zamroni, 2007), including Religious Education as a basic value that is important for students. Religion and Culture have a close relationship in human life. In relation to the formation of individual attitudes and behavior, religion and culture, having the same important position (Kobylarek, 2014); (Zwingmann et al., 2006), and can not be separated (Friedman as cited by Saihu, 2019).

Likewise, the findings of this study indicate that there are efforts to internalize multicultural values through religious education. Students are given an understanding of multiculturalism on the basis of religion, the holy book. This effort is important to do so that the strengthening of multicultural values in religion becomes a guide for students' lives. Therefore, religious education is one way to internalize multicultural values, because religious education seeks to instill beliefs, attitudes, values in self manifested in behavior. Lickona quoted by Umar also provides an understanding that the internalization of values is a process of strengthening and instilling beliefs, attitudes, values in individuals so that these values become moral behavior (Umar, 2017).

Schweitzer gave his view that religious education provided in every educational institution asserts that all can learn and practice their religion without discrimination. It also supports the creation of harmony and tolerance between religious communities (Schweitzer, 2013). The results of this study indicate that religious values cannot be separated from social and cultural life, it also has implications for the social life of the people. So this research reinforces Sauri's view that religion is related to basic moral or social actions by its rules (Sauri, 2010). Likewise Umar's opinion which states that religious values are the 
glue for the nation is not a cause of conflict between people (Umar, 2018).

Therefore, religious values must be combined with multicultural values in heterogeneous societies such as in Indonesia. Research conducted at Manado State University as a miniature of Indonesia's diversity shows that the internalization of multicultural values is very important for the education of students in tertiary institutions.

The religious values contained in every attitude and behavior of the life of the nation and state should be the glue in living life in the midst of heterogeneity in Indonesian society which is so diverse both in terms of ethnicity, race, class and religion. Society as a means of implementing the values of belief in God through religious ritual worship, the community as well as a preserver of ideological and cultural messages to be used as a guide for Indonesian citizens in the nation and state

\section{CONCLUSION}

Multicultural education is a demand to instill moral values of diversity. Multicultural education needs to be applied in formal educational institutions as part of the education curriculum. The inculcation of values of equality and togetherness in diversity especially in heterogeneous societies must be part of multicultural education. Because this can anticipate conflicts due to cultural differences. reduce prejudice, establish communication to increase understanding and minimize communication errors in order to establish positive interactions with people who are "different" is an attempt to instill moral values in understanding diversity.

In addition, strengthening religious education becomes a religious foundation so students understand the meaning of difference as a gift from God. On the other hand, supporting the role of educators as a model for good moral attitudes and behavior, especially in internalizing multicultural values is very important for multicultural education in tertiary institutions.

\section{REFERENCES}

Ainul Yaqin, M. (2005). Pendidikan Multikultural: Cross-Cultural Understanding untuk Demokrasi dan keadilan. Pilar Media.

Andersen, \& Cusher. (1994). Multicultural and Intercultural Studies (C. Marsh (ed.)). Prentice-Hall.

Baidhawi, Z. (2005). Baidhawi, Zakiyuddin, Pendidikan Agama Berwawasan Multikultural. Erlangga.

Bruch, P. L., Highbee, J. L., \& Lundell, D. B. (2004). Multicultural education and developmental education: A conversation about principles and connections with James A Banks. Research \& Teaching In Developmental Education, I, 3-17.

Bruch, P. L., Jehangir, R. R., Lundell, D. B., Higbee, J. L., \& Miksch, K. L. (2005). Communicating across differences: Toward a multicultural approach to institutional transformation. Innovative Higher Education, 29(3), 195-208.

https://doi.org/10.1007/s10755-005-1936-z
Dewantara, J. A., Suhendar, I. F., Rosyid, R., \& Atmaja, T. S. (2019). Pancasila as Ideology and Characteristics Civic Education in Indonesia. International Journal for Educational and Vocational Studies https://doi.org/10.29103/ijevs.v1i5.1617

Hakam, K. A., \& Nurdin, E. S. (2016). Metode Internalisasi Nilai-Nilai. Mulana Media Grafika.

Ibrahim, R. (2013). Pendidikan Multikultural: Pengertian, Prinsip, dan Relevansinya dengan Tujuan Pendidikan Islam. ADDIN, 7(1), 129-154.

https://doi.org/10.30957/edusiana.v4i1.3

Iqbal, M. M. (2014). Pendidikan Multikultural Interreligius: Upaya Menyemai Perdamaian dalam Heterogenitas Agama Perspektif Indonesia. Sosio Didaktika, 1(1), 89-98. https://doi.org/10.15408/sd.v1i1.1209

Kerebungu, F., Pangalila, T., \& Umar, M. (2019). The Importance Of Multicultural Education As An Effort Towards Indonesian National Awareness. https://doi.org/10.2991/icss-19.2019.120

Kobylarek, A. (2014). Education and Culture Society. International Scientific Journal, 2.

Liliweri, A. (2005). Prasangka \& Konflik: Komunikasi Lintas Budaya Masyarakat Multikultural. LKiS.

Miftakhul, A., Harmanto, H., \& Sunarto, S. (2020). Impact Multicultural Education: Case study in Social Studies Learning. In International Journal for Educational and Vocational Studies. https://doi.org/10.29103/IJEVS.V2I5.2500

Miles, M. B., \& Huberman, ;A Michael. (1992). An Expanded Sourcebook Qualitative Data Analysis. In Archives of Gynecology and Obstetrics. https://doi.org/10.1007/BF02759913

Paul-Binyamin, I., \& Haj-Yehia, K. (2019). Multicultural education in teacher education: Shared experience and awareness of power relations as a prerequisite for conflictual identities dialogue in Israel. Teaching and Teacher Education, 85, 249-259. https://doi.org/10.1016/j.tate.2019.06.021

Pradipto, Y. D. (2005). Pemahaman Multikultural dan Pendidikan Multikultural. Kompas.

Saihu, S. (2019). Pendidikan Pluralisme Agama: Kajian tentang Integrasi Budaya dan Agama dalam Menyelesaikan Konflik Sosial Kontemporer. Jurnal Indo Islamika, 9(1), 67-90.

https://doi.org/10.1017/CBO9781107415324.004

Sauri, S. (2010). Membangun Karakter Melalui Pembinaan Profesionalisme Guru Berbasis Pendidikan Nilai. Jurnal Pendidikan Karakter, 2(2), 1-15.

Schweitzer, F. (2013). Religious individualization: New challenges to education for tolerance. British Journal of Religious Education, 29(1), 43-50. https://doi.org/10.1080/01416200601037551

Sugiyono. (2017). Download Metode Penelitian Kuantitatif Kualitatif dan $R \& D$. Alfabeta. 
Umar, M. (2017). Internalisasi Nilai Kedamaian melalui Pendidikan Kedamaian sebagai Penguatan Pembangunan Karakter pada Masyarakat Heterogen. Waskita, 1(1), 77-98.

Umar, M. (2018). Pembinaan Kedamaian Hidup Beragama melalui Optimalisasi Pendidikan Agama. Jurnal Ilmiah Iqra'. https://doi.org/10.30984/jii.v10i1.588

Zamroni. (2007). Pendidikan dan Demokrasi dalam transisi (Prakondisi menuju Era Globalisasi. PSAP Muhammadiyah.

Zwingmann, C., Wirtz, M., Müller, C., Körber, J., \& Murken, S. (2006). Positive and Negative Religious Coping in German Breast Cancer Patients. Journal of Behavioral Medicine, 9(6), 517-553.

https://doi.org/10.1007/s10865-006-9074-3. 